\title{
LEGAL PROBLEMS OF INFLATION
}

\author{
Rt Hon Sir Ivor Richardson*
}

The article reviews the efforts by Governments, Courts and professional accounting bodies to mitigate the hugely damaging effects of the high inflation of the 1970s and 1980s on the economy and the wider public. The Consumer Price Index brings out that impact recording that in 1990 a New Zealand dollar was worth less than one-eighth its value in 1970.

The article traces the development of the treatment of inflation by those bodies during that period and by the Courts since then. It goes on to highlight various areas of the law where inflation has continued to cause problems, focussing on contract and commercial law, damages in tort, taxation and succession to property including trusts, wills and family breakdown.

\section{INTRODUCTION}

At different times in our history, and notably for around 20 years in the 1970s and 1980s, conventional historical cost accounting methods were under sustained and widespread challenge. They had failed to provide adequate information as to the impacts of changes in costs, prices and values. The endless complaints led to parallel governmental inquiries in New Zealand, the United Kingdom and Australia and to considerable efforts on the part of professional accounting bodies in New Zealand and some other jurisdictions to develop appropriate reporting standards for business entities.

That clamour for change died down as the inflationary tide largely receded in those countries over the next few years. But, practical legal problems from inflation continue to be significant in a range of common law and statutory situations outside the presentation of accounts for tax and other reporting purposes.

This article reviews inflation accounting in New Zealand and goes on to highlight various areas of the law where inflation caused and has continued to cause problems. It focuses on contract and commercial law, damages in tort, taxation and succession to property including trusts, wills and family breakdown, ending with some brief concluding comments. The Appendix provides material on inflation in New Zealand from 1914 to 2013 drawn from official published records. The

* Distinguished Fellow, Faculty of Law, Victoria University of Wellington. 
Consumer Price Index rose rapidly from 111 in 1970 to 964 in 1990 and 1058 in 1995. In the last 20 years inflation has averaged around three per cent annually.

Where protection is sought against future inflation, appropriate indexes or review clauses may be employed and proportions or percentage increases applying to bare monetary amounts may be used in documenting transactions. In some situations the legislature has responded to the problem. In a range of cases Courts by their interpretation of the legislation or of the documentation of transactions have also responded. Results have been variable because of uneven awareness of the impacts of inflation on the part of counsel and individual judges. Judges do not come from a common mould. Many may have a general awareness of inflation but, without checking appropriate indexes and relevant commercial interest rates, may not fully appreciate the impact over the material period. Reviewing and appropriately critiquing particular judgments or, more generally, a range of cases is the best window for assessing their evaluation of inflationary impacts.

There are ample illustrations from this country in most of these areas. The highly-controlled New Zealand economy of the 1970s and early 1980s suffered the adverse impacts of inflation much more than the economies of Australia or the United Kingdom. The article's primary focus is on New Zealand law and practice in order to bring out how a considerable number and range of cases in which inflation was an issue were determined.

\section{INFLATION ACCOUNTING IN NEW ZEALAND}

\section{$A$ The McKay Paper at the 1975 Law Conference}

Mr I L McKay was a leading practitioner and company director, later to be appointed directly to the Court of Appeal. His paper at the 1975 triennial New Zealand Law Conference, which was published along with the conference's vigorous discussion, was a catalyst alerting lawyers and the public to the damaging effects of inflation on the New Zealand economy and society and the responsibilities lawyers faced. ${ }^{1}$

Mr McKay emphasised that the people who were the first victims of inflation's impacts were those who could least afford it - the retired person, the widow, the young married couple, the small saver, and the separated wife with children to care for; that business was being undermined because of a reliance on traditional accounting methods, which showed paper profits that concealed the impact of inflation; and that wage demands were based on the false picture painted by company accounts, with Government price controls exercised on the same unreal basis and taxation levied on paper profits.

Mr McKay saw the lawyer's role as being: ${ }^{2}$

1 I L McKay The Legal Problems of Inflation (1975) NZLJ at 395.

2 At 397 
(1) to advise his clients and draw up their contracts and other instruments in such way as will protect them where possible from the adverse effects of inflation;

(2) to influence the course of the common law in adapting to meet the new problems which confront it;

(3) to press for legislative intervention where appropriate; and

(4) to assist in formulating the guidelines for government action to reduce and control inflation, and to ensure that any such intervention is taken with proper regard for its effect on individuals.

Mr McKay then embarked on an extended review of how to mitigate the effect of inflation under existing law focussing on indexation, the use of review clauses and of proportions rather than monetary amounts in documenting transactions, giving numerous practical illustrations and pointing to the responsibility of counsel and the courts to develop the common law in a way that would avoid injustice.

\section{B Inflation Accounting in New Zealand: 1975 to 1985}

\section{The Committee of Inquiry into Inflation Accounting}

The Law Conference was in August 1975. There was a change of Government at the general election in November 1975. The establishment of the Committee of Inquiry into Inflation Accounting was announced on 22 December $1975^{3}$ and it reported its conclusions nine months later, in a report of some 270 pages. $^{4}$

The Terms of Reference required the Committee to report to the Minister of Finance on: ${ }^{5}$

(a) the results of its deliberations and recommend the accounting standards and methods which, in the Committee's opinion, are best suited to the needs of New Zealand;

(b) the nature and extent of any changes in tax policy that may be desirable having regard to the Government's need to maintain an adequate level of revenue;

(c) the implications of the recommended changes on prices and on incomes of the various groups affected, and on policies in relation to the determination of same;

3 The members of the Committee were I L M Richardson, chair; Dr D T Brash, economist and later longserving Governor of the Reserve Bank; Mr R P Kellaway, Chief Deputy Commissioner of Inland Revenue; Mr P S Stannard, chartered accountant and company director; and $\mathrm{Mr} \mathrm{H} \mathrm{M}$ Titter, also a chartered accountant and chief executive of Feltex.

4 The Report of the Committee of Inquiry into Inflation Accounting (New Zealand Government Printer, Wellington, 1976).

5 At 3 . 
(d) the implications of the Committee's recommendations in terms of the Companies Act, Partnership Act, and any other Acts and the common law.

The inquiry involved analysis of research in New Zealand and overseas. The current cost accounting model ultimately proposed systems for treating monetary assets and liabilities, as well as more straightforward matters, such as trading stock and depreciation.. Parallel inquiries by accounting bodies in the United Kingdom and Australia made recommendations and a start was made to introduce changes for tax purposes.

After an initial flurry of some legislative activity and despite a decade of efforts to develop new reporting standards years, particularly by the New Zealand Society of Accountants, the National Government focussed on reducing the effects of inflation on the New Zealand public. The immediate steps taken by the new Labour Government following the July 1984 general election and changing impacts in our overseas markets largely ended the inflation accounting chapter.

Why, then, did it end in that way? I suggest that when different segments of the community fully appreciated what the impacts of the necessary implementation changes would be, they saw more disadvantages than advantages.

For many years New Zealand had a relatively fixed exchange rate, extensive price controls and fairly high income taxes. The economic and social gains from adopting an appropriate form of inflation accounting were seen to be long-term. Prices would initially rise and flow through to consumers. Tax revenue would be affected in the short term. As company directors foresaw, shareholders would see lower profits for distribution and the market value of their shares affected. There was reluctance in the business and governmental worlds to depart from historical cost accounting, which for centuries had underpinned the calculation of economic performance. Eventually, as explained in Part III of this article, radical changes in the structure of the economy since the mid 1980s moved New Zealand from a highly controlled economy to a market economy where the New Zealand dollar found its own level in open trading and where monetary policy was largely the responsibility of an independent Reserve Bank.

However, it is worth recording the legislative changes and the steps that were taken by the accountancy bodies.

\section{Legislative changes}

The Income Tax Amendment Act (No 2) 1977 enacted three ameliorating provisions. First, s 46 added s 167A to the principal Income Tax Act 1976, allowing a 5 per cent addition to the opening value of trading stock when calculating the gain/loss adjustment for income tax purposes.

Secondly, s 11 (1) added para (51) to the list of incomes exempt from income tax any premium income received on redemption of inflation-adjusted bonds in s 61 of the 1976 Act. The Finance (Inflation-adjusted Bonds) Act 1977 passed a few weeks earlier set the scene. Section 2 (1) provided 
for the issue of bonds in respect of money borrowed under the New Zealand Loans Act 1953 and, in addition to interest payable on them, for there to be:

... payable to the holders thereof at the time the bonds are redeemed a further amount that may be

calculated on the basis of the inflation amount occurring between the issue of the bonds and their

redemption.

Thirdly, s 15 amended s 110 of the 1976 Act by increasing the depreciation allowance in respect of motor cars used for business purposes acquired on or after 1 April 1977 by $\$ 1,000$ to $\$ 7,000$ from the $\$ 6,000$ that applied to them in the previous income year.

The Income Tax Amendment Act 1978 continued the 1977 pattern by increasing the depreciation allowance in respect of such motor cars acquired between 1 April 1977 and 31 March 1978 by $\$ 1,000$, from $\$ 7,000$ to $\$ 8,000$. However, at the very lengthy third reading of the Bill, ${ }^{6}$ the Government repealed s 46 and s $167 \mathrm{~A}$ as they were no longer considered necessary. The Hon J K McLay noted that liquidity in the business sector had improved and that stock levels had steadied. ${ }^{7}$ He and other Government speakers emphasised how the Bill provided for substantial tax reductions across the board.

\section{The Society of Accountants' Development of Current Cost Accounting}

I turn, next, to the Society of Accountants' continuing efforts to develop current cost accounting and the difficulties encountered along the way. ${ }^{8}$ As far back as 1976 some major New Zealand - listed companies, including Challenge Corporation Ltd, included in their published annual report sections on accounting for inflation. ${ }^{9}$

Following lengthy discussions the Society of Accountants promulgated $C C A-1$ (initially for listed companies) "to reflect the effects of rising prices" in 1982.

The papers published by the Waikato Inflation Accounting Research Project at the University of Waikato are also in point, particularly the paper by R Peterson, H E Gan and K L Lim. ${ }^{10}$ The paper noted that the standard for financial statements beginning on or after 1 April 1982 became operational in March 1982. It applied to companies listed on the Stock Exchange. It was to be reviewed on an ongoing basis, amended as justified and was to be reviewed comprehensively after

6 (26 September 1978) 421 NZPD 3759-3792.

7 At 3770 .

8 The Government's Task Force on Taxation 1981-1982, which reported in April 1982 (Wellington, Government Printer), also explored the inflation adjustment of business income.

9 Cited by Professor T K Cowan in "An Exciting Future for Inflation Accounting" (1985) 64 The Accountants Journal at 52-54.

10 R Peterson, H E Gan and K L Lim "CCA - the day after" (1984) 63 The Accountants Journal 88. 
no more than three years. ${ }^{11}$ One-hundred-and-forty-seven companies were surveyed. The results were discussed with the individual companies and are commented on in the paper.

The authors summed up: ${ }^{12}$

The results of the standard were disappointing but not unexpected. CCA constitutes a radically different system of accounting from the traditional model and the Society had ample warning that the business community was unhappy with the CCA proposals. One would have expected that the Society would have heeded this warning in the drafting of the proposals and, more importantly, in the marketing of the product. The Society's whole approach to the marketing of CCA has been decidedly low-key. If CCA is worthwhile, and we think it is, then the Society should be prepared to spell out the benefits of the new system to both preparers and users of accounting reports. In other words the Society must get out and sell the product.

\section{MONEY}

The Laws of New Zealand has a title devoted to "Money" that sets the scene as to how the legislature, the executive and the courts have responded to the problems that have continued to arise from inflation. ${ }^{13}$ Interestingly, there is not a stand-alone chapter in either Halsbury's Laws of England, Halsbury's Laws of Australia or The Laws of Australia. Relevant aspects are covered in England, primarily in the chapter "Financial Services and Institutions". ${ }^{14}$

The Preface to the New Zealand title, published in 2000, reads: ${ }^{15}$

There have been radical changes in the structure of the New Zealand economy since the mid 1980s. It has moved from a highly controlled and regulated economy to a market-driven economy, subject to and affected by market forces and stimuli, both domestic and international.

Changes in many of the operations of many of the matters covered by this title have been at the heart of the move to a more open economy. The previous system of a relatively fixed exchange rate, supported by tight controls on foreign exchange transactions, has been replaced by a system where the New Zealand dollar must find its own level in open trading in an international market place. Monetary policy, previously the preserve of politicians and capable of being used in an attempt to achieve a wide range of policy objectives, is now the responsibility of an independent central bank, is to be used for a clearly stated statutory purpose, and is subject to a transparent agreement with the executive government. The

11 At [5.16].

12 At 91.

13 Laws of New Zealand Money at [i].

14 See [1276-1278], [1299-1310], [1313], [1362-1366] and [1390-1399]. See also Guy David "Money in Canadian Law" (1986) 65 Can B R 193.

15 At [vii]. 
Reserve Bank of New Zealand Act 1989 accordingly represents an important milestone in New Zealand economic history, as well as having an important place in New Zealand law.

$\operatorname{Re} Z$, in which the Court of Appeal dismissed the appeal from the Supreme Court decision, is an early judicial response to the impact of inflation on a testamentary disposition. ${ }^{16}$ The Judge referred at some length to Mr McKay's New Zealand Law Conference paper. ${ }^{17}$ The testator died on 24 December 1970 leaving a widow aged 50 from a second marriage of 20 years' duration, and a former wife and adult children from his first marriage. The widow claimed under the Family Protection Act 1955 for further provision from the estate.

In Mahon J's judgment of 17 May 1977, the annuity under the will of $\$ 40$ per week was increased to $\$ 100$ per week from 1 January 1977, with quarterly adjustments to reflect changes in the All Groups Consumers Price Index. The Judge concluded that the testator must be taken to be aware that consumer prices had risen each year for the past five years and should have foreseen that an annuity of $\$ 40$ would be insufficient to maintain the widow in the immediate succeeding years. ${ }^{18}$

In that regard, Mahon J was required by statute to have regard to all relevant circumstances that existed and were foreseeable at the date of hearing, not only those foreseeable at the date of death. The Laws of New Zealand adds, citing Williams $v$ Aucutt, ${ }^{19}$ that when deciding how a breach is to be remedied, changes in asset values up to the date of hearing are relevant. ${ }^{20}$

Morris $v$ Ritchie is an even earlier reported recognition of market forces affecting the value of currency. ${ }^{21}$

In that case, the appellant was convicted of unlawfully carrying on the business of a gold coin dealer without holding the required licence. He argued that sovereigns, which were New Zealand currency, could by law only be exchanged for currency in a different form (for example, florins, shillings and pence). Therefore, paying more than the face value for sovereigns could not be construed as a purchase and the Board of Trade (Coined Gold) Regulations 1932 were meaningless.

Ostler J rejected the argument: ${ }^{22}$

$16 \operatorname{Re} Z$ [1977] 2 NZLR 444 (HC); [1979] 2 NZLR 495 (CA).

17 At 450

18 At 488 .

19 Williams v Aucutt [2000] 2 NZLR 479 (CA).

20 Laws of New Zealand, above n 13, at [4].

21 Morris v Ritchie [1934] NZLR (CA), at 196.

22 At 197. 
It is a matter of common knowledge that ... gold has now reached a price of over $£ 7$ per ounce; that sovereigns are worth more than thirty shillings each; that there has sprung up a considerable traffic in them, there being many persons ready to purchase them at a premium and to melt them down in order to obtain part of the profit of their gold-content ...the object of the regulations was to prevent the illegal melting down of such coins and their export as gold. ...It is taken by the purchaser not as current coin of the realm, but as a piece of gold of standard fineness, and it is bought as gold for the purpose of making a profit on the gold.

The contrary argument was clearly hopeless, even if it is unclear how Ostler $\mathrm{J}$ had judicial notice of the particular market prices.

\section{TAXATION}

Revenue law is one field where the courts have usually been totally unwilling to countenance recognition of changes in the money value of assets and liabilities. The impact of inflation has arisen in New Zealand in two distinct situations in cases which went to the Privy Council.

It first arose in Holden $v$ Commissioner of Inland Revenue. ${ }^{23}$ New Zealand residents with sterling funds remitted them to New Zealand by purchasing United Kingdom securities and immediately reselling them in New Zealand for more than would have been received had those funds been remitted through the banking system.

There were three well-known and legitimate ways in which, at the material times, sterling funds could be remitted to New Zealand: (1) the funds could be remitted to New Zealand through the banking system at the official rate of exchange; (2) the funds could be sold to another New Zealand resident for New Zealand currency provided that the sale was effected at the current official rate of exchange; and (3) the funds could be used to purchase foreign assets, which could then be sold for New Zealand currency in New Zealand.

Two points were in dispute before the Privy Council. The first was whether the securities were acquired for the purposes of sale within s 88(1)(c) of the Land and Income Tax Act 1954. The Court of Appeal in Holden and in the earlier decision in Commissioner of Inland Revenue v Hunter ${ }^{24}$ unanimously found for the Commissioner and the Judicial Committee upheld that conclusion.

The second was whether a taxable profit was made on the sale of the securities. The Judicial Committee upheld the dissenting judgments of Turner $\mathbf{J}$ on this point in both Holden and Hunter.

Delivering the opinion of the Judicial Committee, Lord Wilberforce accepted, as the Appellant contended, that: 25

23 Holden v Commissioner of Inland Revenue [1974] 2 NZLR 52 (PC).

24 Commissioner of Inland Revenue v Hunter [1963] NZLR 3339 (CA).

25 At 58 . 
... in a matter in which taxation is involved, it is insufficient to look too broadly at the 'substantial result' of what was done. Analysis must be made of the method actually chosen by the taxpayer. If he has made use of the method which brings him within a taxing provision, then the tax attaches. But this analysis does not, in their Lordships' opinion, lead to any different result. The essential fallacy of the Commissioner's argument, in their Lordship's opinion, lies in valuing the sterling funds, which it was sought to remit, at the official rate. The argument that they should be so valued may be answered in the words of Turner P by saying that the funds must be valued for what they were worth in the better market in a real sense. Another way of putting it is to say that sterling funds in London had a premium value to a New Zealand resident. This in fact they had, otherwise the premium would not have existed, for a New Zealand resident could only have obtained them by operating the taxpayer's method in reverse - that is by purchasing United Kingdom securities with New Zealand currency, at a premium, and then selling them for sterling. Funds available in London must be treated as having, for a New Zealand resident, the same value as he would have had to pay to obtain them.

Lowe $v$ Commissioner of Inland Revenue is the second Privy Council case concerning the impact of inflation. ${ }^{26}$ The question was whether inflation should have been taken into account by the Commissioner when calculating the profits of a taxable sale of land. The appellant acquired 10 acres of land in 1961 for market gardening but decided in 1963 to divide and develop the land into what ultimately became 36 lots for sale as housing sites. The six sales in question were in the tax year beginning 1 April 1973. The Commissioner calculated the profit at $\$ 15,566.50$, that being the difference between the net sale price of $\$ 29,366.50$ and the purchase and development costs of $\$ 13,800$ attributable to six lots at the average rate of $\$ 2,300$ per lot.

In the Court of Appeal the appellant failed on all the grounds advanced against the assessment. ${ }^{27}$ The inflation argument was the only ground pursued in the Privy Council.

The Judicial Committee per Lord Templeman ended its very short judgment in this way: ${ }^{28}$

The appellants submitted that Parliament could not have intended that an unfair and unjust method of computing profits or gains should be employed, and that in connection with disposals of land over a lengthy period, historic cost accounting was unfair and unjust because it only provided an illusion of profit without a corresponding increase in wealth. Therefore, it was argued, the Courts are entitled to recognise and reject the illusory profit deduced from historic cost accounting and to substitute the true profit calculated by an appropriate method of current cost accounting, which takes inflation into account.

26 Lowe v Commissioner of Inland Revenue [1983] NZLR 416 (PC).

27 Lowe v Commissioner of Inland Revenue [1981] NZLR 326 (CA).

28 At 417. 
This appeal must however be determined not by fashionable theories but by practice and law. It is clear that by the practice and law of New Zealand a profit or a loss for income tax purposes can only be measured in the present circumstances by the difference between dollars expended and dollars received.

\section{CONTRACTS AND COMMERCIAL LAW}

\section{A Focus on Law and Practice}

The introductory section of this article noted that the primary focus is on New Zealand law and practice.

Lord Wilberforce's statement in Miliangos $v$ George Frank (Textiles) Ltd emphasising the role of professional practice in the inter-relationship of law and practice, widely influential at the time, is still a reliable guide to travellers in these difficult uncharted waters. ${ }^{29}$

The case concerned a contract made in Switzerland between a Swiss seller of goods and an English buyer that stipulated payment in Swiss francs. The goods and invoices were delivered but the price was not paid and the associated bills of lading were dishonoured on the due dates. The crucial question was whether an English judgment reflecting practical inflation implications could be given in Swiss currency rather than in sterling, as precedent seemingly required.

In Schorsch Meir GmbH v Hennin, which was much discussed in Miliangos, the Court of Appeal held that the English rule that judgments be expressed only in sterling should be discarded and that judgments should be given in the currencies of foreign countries when the foreign currency was that of the contract and the currency of payment. ${ }^{30}$

Lord Denning, with Foster J concurring, gave two reasons: first, that Article 106 of the Treaty establishing the European Community required that result in that case where the German company sued for payment for goods supplied under the contract expressed in German currency; and, secondly, that inflationary impacts and procedural changes required it. Lord Denning explained: ${ }^{31}$

Why have we in England insisted on a judgment in sterling and nothing else. It is, I think, because of our faith in sterling. It was a currency which had no equal. Things are different now. Sterling floats in the wind. It changes like a weathercock with every gust that blows. So do other countries. This change compels us to think again about our rules ...

He went on to explain why the reasons governing old procedures and practices no longer applied.

29 Miliangos v George Frank (Textiles) Ltd [1976] AC 443.

30 Schorsch Meir GmbH v Hennin [1975] QB 416 per Lord Denning MR. and Foster J for the majority, Lawton LJ dissenting,

31 At 424. 
In Miliangos the House of Lords upheld the Swiss seller's argument. Lord Simon of Glaisdale dissented, concluding that "this type of issue is unsuitable for reform by the judiciary [and would require] a wide range of advice, official especially but also commercial." 32 Lord Wilberforce delivering the leading judgment said: ${ }^{33}$

But if I am faced with the alternative of forcing commercial circles to fall in with a legal doctrine which has nothing but precedent to commend it or altering the document to conform with what commercial experience has worked out, I know where my choice lies. The law should be responsive as well as, at times, enunciatory, and good doctrine can seldom be divorced from sound practice.

\title{
B Interpretation of Statutes to Allow for the Impact of Inflation
}

In the introduction I noted that in a range of cases Courts had responded to the impact of inflation in their interpretation of the legislation or in the documentation of the transactions.

The focus at this point is on contract and land transactions. Similar situations arise in tort, especially where the calculation of damages for future loss is involved, and in succession to property including trusts, wills and family breakdown.

What can be drawn from judges' evaluations of inflation may depend on their interpretation and assessment of the particular legislation or common law rule. In contract cases the discretionary provisions of the contract statutes may be applicable and will be noted shortly when discussing House v Jones. ${ }^{34}$

The relevant provisions of the Judicature Act 1908, the High Court Rules and the District Courts legislation may also be applicable. Put briefly, in the absence of any express limiting provision, the Court's basic decision is discretionary, and that discretion is to be exercised as the justice of the case requires. ${ }^{35}$ The general purpose of the power is to enable the Court to properly compensate a successful plaintiff for loss. ${ }^{36}$

McGechan on Procedure conveniently sets out the prescribed rates initially under s 87 of the Judicature Act 1908 and s 7 of the Judicature Amendment Act 1974 and, subsequently, under the respective Judicature (Prescribed Rate of Interest) Orders. ${ }^{37}$ The prescribed rate is a maximum rate, not an indication of the rate that the Court should award, which remains a discretionary assessment

\author{
32 At 490 . \\ 33 At 464 \\ 34 House v Jones [1985] 2 NZLR 288 (CA). \\ 35 Wilson \& Horton Ltd v Attorney-General [1997] 2 NZLR 513 (CA); Day v Mead [1987] 2 NZLR 443 (CA). \\ 36 See for example, Day $v$ Mead, above n 35 \\ 37 McGechan on Procedure (looseleaf ed, Thomson Reuters) at [J87.05].
}


not to be interfered with on appeal except where the lower Court judge was shown to have erred in principle or to have been plainly wrong.

The prescribed rates are:

(i) Up to 29/10/74: 5 per cent per annum

(ii) $20 / 10 / 74$ to $31 / 3 / 80: 7.5$ per cent per annum

(iii) $1 / 4 / 80$ to $31 / 7 / 02: 11$ per cent per annum

(iv) $1 / 8 / 02$ to $30 / 6 / 08: 7.5$ per cent per annum

(v) $1 / 7 / 08$ to $30 / 6 / 11: 8.4$ per cent

(vi) $1 / 7 / 11$ to date: 5 per cent per annum.

The rates prescribed between 1970 and 2002 were a totally inadequate response to inflation affecting interest rates over those 32 years. ${ }^{38}$

Three relatively recent decisions of the Court of Appeal bring out different inflation questions. In Drower v Minister of Works, the dispute was over the quantum of the "full compensation" to be paid for land taken under s 42(1) of the Public Works Act 1928 for public works. ${ }^{39}$

In 1975, the Crown had taken land belonging to the claimants. The parties eventually agreed on the values of the lands taken. The payment of compensation was delayed for varying periods of approximately five years. In a number of decisions the Administrative Division of the High Court had held that an inflation factor was to be taken into account, and in Drower the Administrative Division was again asked to make that assessment.

The claimants' counsel advanced six possible approaches to the assessment. Counsel for the Minister rejected all six and contended that a payment of simple interest on the unpaid compensation moneys would provide full compensation. The claimants contended for the application of the Consumer Price Index, plus 2 per cent added for being out of their money over the period of delay in payment. That interest rate was what the Government allowed on its Inflation Adjusted Bonds.

The Administrative Division rejected both arguments and preferred the approach taken in Coomber v Birkenhead Borough Council where the allowance for inflation was reflected in a sum calculated at 10 per cent per annum compounded on the unpaid purchase money. ${ }^{40}$ However, the wider and only issue before the Court of Appeal was the correct means of reflecting the inflation.

38 See the Appendix.

39 Drower $v$ Minister of Works [1984] 1 NZLR 26 (CA).

40 Coomber v Birkenhead Borough Council [1980] 2 NZLR 681 (SC). 
The Court allowed the appeal. ${ }^{41}$

Somers $\mathbf{J}$ considered that nominalism was too deeply entrenched in the law to allow for that approach to be accepted and that an interest rate at ordinary commercial rates such as first mortgage rates, which might have reached 15 per cent per year or even higher, might be expected to take account of the only real risk, namely, that of loss of value. ${ }^{42}$

The majority judgment delivered by Woodhouse P concluded that "full compensation" included compensation for erosion of value and that the Consumer Price Index should be used for indexing. ${ }^{43}$ The final point concerned the payment to be made to the claimants because they had been kept out of part of the capital funds which they were entitled to receive and use in 1975. The majority judgment accepted the evidence of Professor Schmidt, who had explained the possible approaches to making specific allowance for inflation, and considered that a true interest rate of 2 per cent would be appropriate provided that rate itself were indexed to provide for the fact that during the intervening years interest had not been paid.

In The Power Co Ltd v Gore District Council the Court, applying conventional frustration principles, rejected the argument that the massive inflation of the 1970s and 1980s had ended the contract. ${ }^{44}$ Under the agreement between the Southland Electric Power Board and the Gore Borough Council, the statutory predecessors of The Power Co Ltd and Gore District Council respectively, the Board purchased the Council's electricity reticulation system and associated works except for the assets used for its street lighting and its own municipal purposes. The Board covenanted to provide a continuous supply of electricity to the Council for its own purposes and to all present and future consumers within the borough. The agreement included a scale of charges to consumers not to be "higher at any time or under any circumstances" than was set out, subject to adjustments and with other protective provisions, but the charge to the Council for its energy requirements was fixed by clause 15 "at the price of one penny per unit..."

By clause 19 the provisions of the Deed between the parties of 30 March 1927 were binding on them "for all time hereafter."

The case is discussed at length in The Durability of Time Unlimited Legal Arrangements. ${ }^{45}$ It is sufficient for present purposes to cite the relevant passage where the five Judge Court summarised the arguments for The Power Co Ltd and the reasons for rejecting them: ${ }^{46}$

41 Woodhouse P and Roper J for the majority, Somers J dissenting.

42 At 39.

43 At 30

44 Power Co Ltd v Gore District Council [1997] 1 NZLR 537 (CA).

45 I Richardson "The Durability of Time Unlimited Legal Arrangements" (2012) 17 NZACL Yearbook 1 at 15-17; (2013) 19 CLJP/JDCP 1 at 15-17. 
The third argument is that the high level of inflation which had occurred in the 1970s and 1980s was a supervening event of such a character that the obligation on the appellant, as successor to the board, had become radically different from that undertaken or contemplated in the 1927 contract. We conclude that the board gained continuing and long-term advantages in exchange for agreeing to supply at the prices fixed for all time both for the supply to the council and for supplies to the council's consumers. One cannot look merely at the effect of inflation on the prices in the contract without considering also the benefits gained by the board. Looked at as a whole, the effects of the contract have changed in various ways, but not to such a fundamental extent as to have brought it to an end by frustration.

House $v$ Jones highlighted the complications in applying the discretionary relief provisions of the Illegal Contracts Act $1970 .^{47}$

The decline of judge-made common law and the increasing prominence of statutory law are reflected in contract law. The Illegal Contracts Act 1970, the Contractual Mistakes Act 1977 and the Contractual Remedies Act 1979 have partially codified and reformed the common law conferring substantial discretions on the Courts.

Section 7(1) of the Illegal Contracts Act empowered the Court to grant relief against a finding of illegality, rendering the contract of no effect. Subsection 3 went on to provide:

In considering whether to grant relief under subsection (1), and the nature and extent of any relief to be granted, the court shall have regard to-

(a) the conduct of the parties;

(b) in the case of a breach of an enactment, the object of the enactment and the gravity of the penalty expressly provided for any breach thereof;

(c) such other matters as it thinks proper;

but shall not grant relief if it considers that to do so would not be in the public interest.

In 1978 the respondents, Mr and Mrs Jones, were planning to visit England for two years. They listed their farm of 130 hectares for sale. The appellants, Mr and Mrs House, could not arrange mortgage finance. The parties orally agreed to a sharemilking agreement with an option to purchase. The respondents left the property on 23 June 1978 and a few days later the appellants took possession. The purchase price under the written agreement of 3 November 1978 was $\$ 150,000$ if the option was exercised by 1 June 1979 , and $\$ 160,000$ if exercised after that date but by 1 June 1980, when the option to purchase expired.

46 At 540

47 House v Jones, above n 34. 
The appellants' solicitor purported to exercise the option but the procedural requirements of the Land Settlement and Land Acquisition Act 1952 were not complied with and, eventually, the tender of settlement on 25 September 1980 was refused. In May 1981 the appellants sought specific performance of the agreement and relief under the 1970 Act. Judgment went against the appellants on 1 July 1983 within a month after the hearing, and the appeal heard on 14 November 1985 was dismissed on 3 December 1985.

Responding in argument to the obvious point that it would be unjust to allow the purchaser to complete a 1980 transaction paying in 1985 or 1986 dollars, when between 30 September 1980 and 30 September 1985 the Consumer Price Index increased by 77 per cent and over four years during that period the Dairy Farmland Price Index rose by 58 per cent, counsel for the purchasers suggested that the position might be met by an adjustment to the purchase price ordered as a term or condition of validation under the 1970 Act. That submission meant making a new bargain. The appeal failed.

\section{DAMAGES IN TORT}

Attorney-General $v$ Green is an early consideration of the impact of inflation on damages awards. ${ }^{48}$ Mr Green was killed in an accident in the course of his employment by the New Zealand Electricity Department, leaving a wife and young children. The jury awarded $\$ 16,000$ general damages under the Deaths by Accident Compensation Act 1952, which was reduced by 50 per cent for his contributory negligence.

The Court of Appeal dismissed the appeal against the trial Judge's dismissal of the AttorneyGeneral's application for a new trial brought on the ground that the award was excessive.

Turner $\mathrm{J}$ referred to the argument that the probable fall in the value of money, ${ }^{49}$ consequently bringing in its train a likely rise in future wage rates afforded a ground for a greater immediate award. He said: 50

The argument based on the future value of money is in this case best considered as a submission that

future rates of wages may rise in response to inflationary tendencies. ... The tendency of wage rates has

for many years been to increase as the years go by.

In Anscombe v Paul Christie Ltd, the company was a shoe retailer. ${ }^{51}$ Its stock was damaged by flooding for which Mr Anscombe accepted responsibility. He unsuccessfully appealed against the award of $\$ 45,070$ in respect of the cost-related damage to the shoes themselves.

48 Attorney-General v Green [1967] NZLR 888 (CA) per Turner, McCarthy and T A Gresson JJ.

49 At 892

50 At 893

51 Anscombe v Paul Christie Ltd [1991] 2 NZLR 176 (CA) per Richardson, Hardie Boys and Thorp JJ. 
Delivering the judgment of the Court of Appeal Hardie Boys J said: ${ }^{52}$

Due no doubt to the way in which the present case was approached, there was no specific evidence of the replacement cost, only of historical cost. However, one of the assessors referred to the topic, and on the basis of his understanding that inflation was running at 15 per cent, stated that replacement could be 15 per cent higher than that paid for it originally. That was obviously a minimum allowance, for the older the stock the higher the allowance would need to be. If an allowance of 15 per cent is made, replacement cost would be $\$ 94,310 \ldots$ the method adopted for selling the damaged stock meant that the respondent was able to replace only gradually. And by requiring the respondent to bring to account the gross receipts from the sale of the damaged stock, no allowance is made for the overheads incurred in making those sales. There is no evidence as to what they were. But if one instead applies the gross profit margin of 36.91 per cent (which was obtained by an analysis by one of the assessors, and which $\mathrm{Mr}$ Upton [for Mr Anscombe] adopted for the purposes of an alternative method of calculation) and deducts this from the sales receipts, one obtains a figure of $\$ 45,227$, which may be said to be the cost-related value of the stock in its damaged condition. ... if one assumes a replacement cost value of $\$ 94,310$. Then, the diminution in value resulting from the damage can be said to be $\$ 49,083$, this being the difference between replacement cost and the cost-related value of the damaged stock.

Finally, in Addington Timber Co Ltd v Bell, ${ }^{53}$ the defendant in the High Court admitted liability for damage to the plaintiff's forest by the spread of fire, which the defendant had lit on his adjoining land. The principal question to be decided concerned the calculation of the revenue that would have been derived from the damaged trees had they grown to maturity and, in particular, how to take account of inflation. Hardie Boys $\mathbf{J}$ applied a low discount rate of 3 per cent, as had the High Court of Australia in Todorovic $v$ Waller, ${ }^{54}$ adopting the actuarial assessment in that case.

\section{SUCCESSION TO PROPERTY}

\section{A Trusts and Wills}

Section 3 of the Trustee Amendment Act 1974 amended s 4 of the Trustee Act 1956 by adding s 4(1A) - s 4(1E). The 1974 amendment followed from the Report of the Property Law and Equity Reform Committee on Trustees' Statutory Powers of Investment discussed by P N Burgess. ${ }^{55}$

The Committee said: 56

52 At 178.

53 Addington Timber Co Ltd v Bell [1983] New Zealand Recent Law 267.

54 Todorovic $v$ Waller (1981) 150 CLR 402.

55 PN Burgess "Trustee Investments and Inflation" [1971] NZLJ 497.

56 Report of the Property Law and Equity Reform Committee on Trustee's Statutory Powers of Investment (8 March 1970) at 6. 
In our view, the existing statutory power of Trustees in relation to investments is a legacy from the nineteenth century approach to investment in England. This approach, which had as its main object the preservation of capital, was based on the premise that the purchasing power of money remained constant. Clearly, however, this principle has become untenable in modern times when capital is being continually eroded by inflation and by the corresponding depreciation in the value of money.

The Committee, comprising very experienced practitioners, academic specialists and officials, discussed three different approaches and drafted a Bill incorporating its proposals.

The National Government did not take it up. But, following the change of Government in 1972, the Minister of Justice, the Hon Dr A M Finlay, introduced the Bill. Moving the second reading of the Bill, Dr Finlay said: ${ }^{57}$

It has been the practice for many years for draftsmen to include wide powers of investment in wills and trust instruments, including the power to invest in company securities. All that the Bill will do in this respect, therefore, is to allow trustees to do without express authority - that is to say contained in their trust instruments - what they have always been able to do with that authority.

Earlier, the concerns had been that the Bill would divert investment funds away from Government and local body investments. The particular point raised at the second reading was "the possibility of a distortion in investment patterns and some drawing away of funds used for mortgage purposes into shares and equity investments." 58

The Act authorised investment in any of the types of shares and debentures listed in paras (a) and (b) of the new subs (1A) of s 4 issued by any company incorporated in New Zealand that met the criteria set out in subs (1B) requiring that the shares or debentures be listed on New Zealand stock exchanges and, by subs (1C), that the company should have a paid-up capital of $\$ 2.5 \mathrm{~m}-$ which applied to some 70 of the 200 companies listed on the stock exchanges. ${ }^{59}$

By s 3 of the Trustee Amendment Act 1988 "Part II Investment" of the 1956 Act as previously amended was repealed and replaced by a much broader regimen (one of the three approaches considered by the Property Law and Equity Reform Committee in 1970), under s 13 B: "...a trustee exercising any power of investment shall exercise the care, diligence, and skill that a prudent person of business would exercise in managing the affairs of others."

57 (26 March 1974) 390 NZPD 1159 at 1160.

58 At 1163.

59 At 1167. 


\section{B Family Breakdown}

\section{Inflation Problems under the Matrimonial Property Act 1976}

There are two main reasons why inflation has caused and continues to cause problems in family breakdowns in various situations. First, the division of property between the spouses or others in property relationships is complicated because of the time lag between the date the parties separated and the determination of who gets what and then fixing the relevant values. Secondly, inflation adjusting considerations arise whenever payment in respect of particular relationship property depends on future events affecting the immediate parties or their children.

The Matrimonial Property Act 1976 was pioneering social legislation, ${ }^{60}$ aptly described in the long title as:

An Act to reform the law of matrimonial property; to recognise the equal contribution of husband and wife to the marriage partnership; to provide for a just division of the matrimonial property between the spouses when their marriage ends by separation or divorce, and in certain other circumstances, while taking account of the interests of any children of the marriage; and to reaffirm the legal capacity of married women.

The anticipated avalanche of decisions under the Act prompted the New Zealand Council of Law Reporting to publish a special series, Matrimonial Property Act Cases, between 1977 and 1982. Over 750 decisions were helpfully made available to the practising profession, the judges and others interested in those early days.

Only two cases went to the Privy Council: Reid $v$ Reid ${ }^{61}$ and Holt v Holt, ${ }^{62}$ and both were dismissed. In Reid the Judicial Committee emphasised that whether the contribution of the husband to the marriage partnership had clearly been greater than that of the wife was: "essentially the sort of issue where the Courts of the society to which the spouses belong are in a position far superior to that of their Lordships in forming a judgment." And that consideration applied equally to the division of matrimonial property (other than the matrimonial home and family chattels) of 60 per cent to the husband and 40 per cent to the wife favoured by the majority in the Court of Appeal (Woodhouse and Richardson JJ) as against Cooke J's preference for a 75:25 split.

Because of the advantages of having a range of High Court cases available for consideration in the Court of Appeal, the first five appeals were heard over two weeks in March 1979 with judgment in all five being delivered on 30 May 1979. Over the years a large number and wide range of

60 See A H Angelo and W R Atkin "A conceptual and structural overview of the Matrimonial Property Act 1976" (1977) 7 NZULR 237.

61 Reid $v$ Reid [1982] 1 NZLR 147 (PC).

62 Holt v Holt [1990] 3 NZLR 67 (PC). 
appeals were decided, 55 being reported in the NZLR reports between 1977 and 1989, and 48 since then. Not surprisingly, the law has evolved over 35 years.

Superannuation schemes posed special problems. ${ }^{63}$ They were a defined category of matrimonial property under s 8(i) and the total value of the benefits were to be divided irrespective of the fact that some entitlement may have been acquired before marriage. The effects also differed depending on whether the schemes were contributory ${ }^{64}$ or defined benefit schemes. ${ }^{65}$

In Haldane the parties were married for 15 years and separated in 1973. He was an airline pilot and had joined Air New Zealand's superannuation scheme four years before the marriage. The nature and value of the benefits of a contributor in the husband's position depended on the circumstances applying when he left the airline.

The question was whether there should be a proportionate sharing of future superannuation benefits and, if so, how should they be calculated. The trial Judge treated the husband's interest in the scheme as worth only the total of contributions he made during and before the marriage, $\$ 9,737$, on the ground that his only right at the date of separation was to retire from the scheme and obtain a refund of contributions.

The Court of Appeal rejected that approach, concluding, too, that unless the member spouse was on the eve of retirement at separation, it would usually be fairer to make a valuation at the date of separation, rather than order under s 31 that on retirement the husband pay the wife a proportion of the benefit then receivable.

As Cooke J put it: 66

If contingent superannuation benefits have been earned to a significant extent by work before the separation, they should normally be brought into account even though the member spouse's retirement may be many years ahead ... While inflation of a degree not reasonably foreseeable in 1973 has made a major contribution to these [earnings] figures, the 19 years contributory service before separation ... necessarily play a significant part by increasing the multiplier.

In the result the Court valued the husband's interest under the scheme at separation at $\$ 40,000$ and his wife's half share at $\$ 20,000$.

In Callaghan v Callaghan the superannuation scheme was a defined contributions scheme, not a defined benefits scheme as in Haldane. ${ }^{67}$ The Court considered that the actuarial calculations

63 See G J Van Bohemen "Superannuation schemes and the Matrimonial Property Act 1976" (1979-1980) 10 VUWLR 63.

64 Haldane v Haldane [1981] 1 NZLR 554 (CA).

65 Callaghan v Callaghan [1987] 2 NZLR 374 (CA).

66 At 556 . 
undertaken in Haldane are valuable when, for example, there is a sharp contrast between immediately realisable and long-term benefits. In Callaghan, however, the husband contributed 10 per cent of his annual salary with matching contributions from the employer to the Ford Employees' Provident Fund. His interest in the Ford fund could readily be calculated as an accounting figure at any time from the date he joined it until the benefits were paid, and at the date of separation that figure was $\$ 21,949,67$. The Court concluded that the wife's contribution to the marriage partnership would be fairly reflected in the immediately realisable benefit of an equal division of the fund standing to the husband's credit at the date of separation.

Morton $v$ Morton $^{68}$ was an unorthodox treatment of insurance policies. In the absence of evidence to the contrary and without reference to the s 8(i) regime the Judge directed that the insurance policies be divided equally. On appeal neither party challenged his approach but the Court (Cooke and McMullin JJ and Sir Clifford Richmond) characterised it as unorthodox and not contemplated by the Act." However, that equal sharing was the basis of an argument for the appellant wife that it should have led to a finding of equal sharing of the substantial farming assets divided in the lower Court into two-thirds to the husband and one-third to the wife.

Delivering the judgment of the Court, McMullin $\mathrm{J}$ rejected that submission. He reviewed the evidence including material subsequent to the High Court judgment increasing the value of the farm from $\$ 296,770$ to $\$ 378,000$ and upheld the two-thirds one-third division, except for the homestead which fell in terms of $\mathrm{s} 12$ to be divided equally as it had been ordered in the High Court.

Most such cases have tended to focus on the impact of high inflation. But the compounding effect of low inflation over a longish period may be significant. Wicksteed $v$ Wicksteed ${ }^{69}$ makes the point. Noting that inflation rates had been low, Priestley $\mathbf{J}$ concluded ${ }^{70}$ that a three per cent per annum rate would represent a fair and adequate rate to compensate for the loss of purchasing power in the wife's share during the seven years she was denied control of it and would have struck a higher rate of 4.5 per cent because of the husband's actions in exposing the capital to greater risk by advancing $\$ 445,000$ to three daughters on an unsecured, on demand basis.

The Family Court Judge had fixed the interest rate at 7.5 per cent without identifying reasons for doing so. Priestley $\mathrm{J}_{\text {noted }}{ }^{71}$ that that rate was not far removed from the commercial bill rates during that seven year period. On his calculations he concluded that a capital payment award of $\$ 75,000$ to the wife would best meet the interests of justice.

67 Callaghan v Callaghan, above $\mathrm{n} 65$, at 378 per Cooke $\mathrm{P}$.

68 Morton v Morton (1982) 5 MPC 100 (CA).

69 Wicksteed $v$ Wicksteed [2002] NZFLR 28 (HC).

70 At [60].

71 At [54]. 


\section{Drawing the Threads Together}

Four more general comments before I refer to Rose $v \operatorname{Rose}^{72}$ and $M v B^{73}$ and then turn to consider inflation adjustments for future periodic payments.

First, the flood of early cases under the 1976 Act - 750 reported in the MPAC Reports between 1977 and 1982 - in a time of very high inflation naturally brought home to the Courts the need to weigh relevant inflation concerns in their decisions.

Secondly, in providing guidance to the lower Courts, counsel, academic and other legal professionals and others interested in matrimonial property and other cases, the Court of Appeal sought to bring home the significance of evaluating inflationary considerations, emphasising its importance through references to indexes and commercial interest rates.

Thirdly, the 1976 Act created two particular problems, which could only be remedied by amending legislation. Income earning capacity was not matrimonial property, which particularly disadvantaged women whose spouses had been able to increase their own income earning capacity disproportionately during the marriage. Next, the "clean break" principle disadvantaged women who were often left after the marriage with half the property, little income and the care of the children.

Fourthly, we did not have the usual benefits of a further appeal to London when in Reid v Reid the Judicial Committee largely opted out of hearing matrimonial property appeals.

Rose $v$ Rose is a recent judgment of the Supreme Court that raised particular problems arising from the substantial increase in the value of farming assets. Blanchard J for the Court said: ${ }^{74}$

A level of complication is provided by a seemingly unsatisfactory consideration. It is that in many cases a major portion of the increase in value will have been the product of inflation or of a general rise in the value of a certain kind of property (here it is the increase in value of property with a suitability for viticulture). In reality, neither of these factors results from the actions of either party during the marriage, yet the subsection [s $9 \mathrm{~A}(2)]$ none the less requires them to be weighed as contributions to the increase in value. One possible approach would be to put such factors to one side, determine the relativity of the other contributions of each spouse and then divide the inflationary or general increase in the same ratio as the other contributions. In many, perhaps most, instances that would not however, give adequate recognition to the fact that the property was, and remains, separate property (only the increase being relationship property) and that, if it had not been brought to the marriage or acquired during the marriage as separate property, there would have been no asset to produce the inflationary or general gain. Normally the fairer approach is therefore that the ownership of the separate property from which

72 Rose v Rose [2009] NZSC 46; [2009] 3 NZLR 1.

$73 M v B$ [2006] 3 NZLR 660 (CA).

74 At [47]. 
these increases in value sprang should be treated under s $9 \mathrm{~A}(2)(\mathrm{b})$ as a contribution made by the owner spouse. The Court should then evaluate that contribution together with other contributions to the increase in value which it identifies as having been made by the owner spouse, and should weigh the aggregate of those contributions against the identified contributions of the non-owner spouse to that increase.

$M \vee B$, where the three Judges discussed various approaches to the identification and valuation of relationship property and spousal maintenance reaching agreement on the result from their differing perspectives in judgments totalling 274 paragraphs, gives an indication of the complexities of assessments under the (now named) Property (Relationships) Act 1976.

\section{Inflation Adjustments for Future Periodic Payments}

Where protection is sought against future inflation, appropriate indexes or review clauses may be employed and proportions or percentage increases applying to bare monetary amounts may be used in documenting transactions. At the 1975 New Zealand Law Conference I L McKay also stressed the duty of lawyers: $:^{75}$

In the drawing of contracts, wills and settlements or the negotiating of agreements he must take account

of inflation and protect his client wherever possible ... [focussing on the mechanisms just mentioned and giving numerous practical examples].

Price adjustment clauses tailored to various situations, including clauses to take account of fluctuations in the cost of materials are commonly employed in construction contracts ${ }^{76}$; and it is common practice for wills containing pecuniary legacies, particularly those containing contingent pecuniary legacies, to provide, for example, for those sums of money to be "increased on the 1st January of each year by 3 per cent compounding".

In a range of cases, too, Courts by their interpretation of the legislation or of the documentation of transactions have also taken account of inflation. Some cases under this head have already been discussed in earlier sections of the article. Re $Z$ a Family Protection Act decision was discussed in Part III of this article where the widow's annuity was increased to $\$ 100$ per week with quarterly adjustments thereafter to reflect changes in the Consumer Price Index. ${ }^{77}$

Next were two cases, discussed in Part V of this article. In Drower v Minister of Works, where the full compensation for the taking of land including compensation for erosion of value through inflation was in question, the Court of Appeal directed that the Consumer Price Index should be

75 McKay, above n 1, at 397.

76 Kennedy-Grant on Construction Law (2nd ed, LexisNexis, Wellington, 2012) at [14.02-14.17].

$77 \operatorname{Re} \mathrm{Z}$, above $\mathrm{n} 16$. 
applied. House $v$ Jones explored the complications of indexing in applying the relief provisions of the Illegal Contracts Act.

Attorney-General v Green, Anscombe v Paul Christie Ltd and Addington v Paul Christie Ltd, all involving the impact of inflation on damages awards, were discussed in Part V.

Wicksteed v Wicksteed, Morton v Morton, Rose v Rose, Haldane v Haldane and Callaghan v Callaghan were noted under the previous subheading. The latter two reflect the significant difference between defined benefit and contributory schemes. Callaghan, where the defined benefits reflected the defendant's wage increases, was foreshadowed 20 years earlier in Attorney-General v Green, where Turner $\mathbf{J}$ saw the calculation of the probable fall in the future value of money as reflected in the tendency of wage rates to increase in response to inflationary tendencies.

The remaining three cases to be noted are Re Leonard, ${ }^{78}$ Re Townley ${ }^{79}$ and Turnbull $\mathrm{v}$ Turnbull. ${ }^{80}$ Each concerns a different statutory setting.

Re Leonard was a Family Protection Act appeal to the Court of Appeal. The testator died on 25 August 1978 aged 89 survived by seven children, four sons and three daughters. By his will dated nearly nine years earlier he left each daughter a pecuniary legacy of $\$ 4,000$ and some items of furniture. The rest of the estate was divided between the four sons.

The major assets in the estate were two dairy farms and a run-off valued at the date of death at $\$ 246,000$ and revalued in April 1983 at $\$ 652,717$. Thus, the final balance of the estate for death duties purposes was assessed at $\$ 384,000$. With further inflation, that had increased to $\$ 750,000$ by the date of hearing in the High Court.

Two of the daughters applied for further provision under the Family Protection Act. Both were married and in each case the assets of the matrimonial partnership totalled some $\$ 175,000$. The net family assets of each son (excluding the benefits under the will) ranged from $\$ 500,000$ to $\$ 750,000$. Each received another $\$ 250,000$ under the will.

The trial Judge found the sharing of the estate between the sons and daughters was grossly disproportionate and that the underlying reason for the disparity seemed to have been the testator's view that his duty to his daughters ceased when they married. In later years both daughters had cared for the testator. The Judge held that the testator was in breach of his moral duty to his daughters and increased the legacy of each to $\$ 40,000$.

78 Re Leonard [1985] 2 NZLR88 (CA) per Woodhouse P, Richardson and McMullin JJ.

79 Re Townley [1982] 2 NZLR 87 (CA).

80 Turnbull v Turnbull (1982) FLN-12 (2d). 
Three of the sons appealed, contending that the daughters were so well endowed in terms of assets and income that the testator owed no testamentary duty towards them. Not surprisingly, the Court of Appeal dismissed their appeal.

Re Townley was an appeal under the Law Reform (Testamentary Promises) Act 1949. The appellant, a distant relative of the testator who farmed in Southland, and his wife were left a pecuniary legacy of $\$ 300$ under the will and the bulk of the testator's estate went to a Mr Baxter who was known to the testator principally through church affiliations. The testator, a bachelor, had formed a grandfatherly affection for Mr Baxter's son.

The substantial assets in the estate were two farmlets, one at Mataura worth about $\$ 33,000$ at the testator's death and about $\$ 80,000$ at the hearing in the Court of Appeal and the other at Kamahi worth about $\$ 10,000$ at the testator's death and sold for $\$ 46,000$ some years later and before the Court of Appeal hearing.

The plaintiff, also a local farmer, claimed that in 1967 the testator orally promised to leave him his Mataura farmlet in return for services to be rendered by him and that later he repeated the promise. The trial judge accepted his evidence of the promise and that he had acted on the promise by rendering the testator substantial services for some nine years. His wife did so, too. The testator often visited them for meals and baths and to have his washing and sewing done, staying with them occasionally including during his last illness. The judge awarded the plaintiff $\$ 10,000$.

The appeal succeeded. Cooke J said: ${ }^{81}$

Thirdly - and this is probably the most important point in the appeal - there is no express consideration in the judgment of the possibility of giving the claimant a part interest in the property, nor of the relevance in that connection of the fact that the High Court was dealing with the case in June 1981, more than five years after the testator's death. The fall in the value of money over those years is indicated by the inflated value of the farmlets already mentioned.

The three Judges (Cooke, McMullin and Somers JJ) all emphasised the increase in land values in allowing the appeal and arrived at an award of $\$ 25,000$, with Somers $\mathbf{J}$ noting that "the Government valuation of the [promised] land at the testator's death was $\$ 33,000$ and is now about two and a half times as much". ${ }^{2}$

Turnbull $v$ Turnbull was an unsuccessful attempt to have maintenance orders made by consent under the Family Proceedings Act 1980 linked thereafter to an index reflecting inflationary changes.

The structure of the 1980 Act differed markedly from the Family Protection and Testamentary Promises Acts, both of which have three value dates of consequence: the date of the will, the date of

81 At 89.

82 At 95. 
death and the date of hearing of the claim. As well, both provide in respect of appeals that the appellate Court "may, in its discretion, rehear the whole or any part of the evidence, or may receive further evidence, if it thinks that the interests of justice so require. "83

Judge Headifen held that the Family Court had no jurisdiction to make an order tagging in the future a maintenance order to any rate of inflation, explaining: ${ }^{84}$

I take the view that s 72 of the Family Proceedings Act requires this Court to fix an amount that is payable as a firm figure. That is perfectly clearly the intention of the legislature if one has regard to subs (2) and subs (3) of s 72 ... Subsection (2) states: 'In determining the amount that is payable' not an amount. And furthermore, in subs (3) again the words appear: 'In determining the amount that is payable'. That indicates in my judgment a definite figure ...The Court may from time to time in respect of any maintenance order make an order varying such maintenance order. If one goes through the provisions of s 99, one finds again: '[t]he Court may from time to time ... make an order varying a maintenance order ... I take the view that the Family Proceedings Act requires the Court to fix a definite amount for maintenance. If circumstances change, such as an inflationary situation as envisaged by counsel for the applicant, then the parties can file an order by consent agreeing to an increase in maintenance, or the matter can be heard. But the Court cannot in my judgment make an order the amount of which is uncertain, but depends on some statistical index of inflation or consumer price index or the like.

\section{CONCLUSION}

In Part VIIB of this article, I commented on the conjunction of the mass of cases in the early years of the Matrimonial Property Act and very high inflation as focussing on the need to weigh relevant inflation concerns by checking appropriate indexes and commercial interest rates. Those were the positives. The two limiting factors were the absence of guidance usually provided by a further appeal to the Privy Council and the reach of the 1976 Act itself: income earning capacity was not matrimonial property and the "clean break" principle tended to disadvantage women. It seems unnecessary to repeat or expand on those observations.

Next, the article has not attempted to discuss all the complications involved in identifying and valuing any inflation component in dividing future income earning capacity and redressing economic disparity on family breakdown or the policy implications in that regard of the (now named) Property (Relationships) Act $1976 .{ }^{85}$

83 See Family Protection Act, s 15(5) and the Testamentary Promises Act, s 15A (5).

84 Turnbull v Turnbull, above n 80, at 17.

85 Mark Henaghan and Bill Atkin (eds) Family Law Policy in New Zealand (4th ed, LexisNexis, Wellington, 2013 ) is a mine of informed discussion on relationship property and other family policy questions. 
Finally, only a handful of the cases discussed or mentioned in the article, notably $M v B$ and Rose $v$ Rose, were decided in the last 20 years. The reason is clear. Over the last 20 years inflation has averaged at only around three per cent annually, which does not ordinarily encourage the legislature or the Courts (except in cases such as Wicksteed $v$ Wicksteed) to grapple with its implications-knowing, too, that in drawing contracts, wills, and settlements and in negotiating agreements lawyers can provide protection from the adverse impacts of inflation. ${ }^{86}$

\section{APPENDIX I: INFLATION IN NEW ZEALAND FROM 1914 TO 2013}

The New Zealand Official Yearbook was published annually up to 2010. Since then information in relation to inflation has been accessible on Statistics New Zealand's website.

Part III notes that monetary policy is now the responsibility of the Reserve Bank of New Zealand under the Reserve Bank of New Zealand Act 1989 and is subject to agreement between the Bank and the Government. The 2010 Yearbook records that the policy targets agreement between the Minister of Finance and the Governor of the Reserve Bank initially required the Bank to maintain Consumer Price Index inflation in the range of 0-2 per cent, changed to 0-3 per cent in December 1996 and in September 2002 (and retained in the December 2008 agreement) to 1-3 per cent range on average in the medium term. ${ }^{87}$

The Consumer Price Index measures changes in prices of goods and services purchased by New Zealand households and is reviewed regularly to ensure the basket of goods and services is current and relevant.

$\begin{array}{llllllll}1914 & 21 & 1936 & 30 & 1958 & 72 & 1980 & 363 \\ 1915 & 23 & 1937 & 32 & 1959 & 73 & 1981 & 420 \\ 1916 & 24 & 1938 & 32 & 1960 & 74 & 1982 & 484 \\ 1917 & 27 & 1939 & 34 & 1961 & 76 & 1983 & 501 \\ 1918 & 30 & 1940 & 35 & 1962 & 77 & 1984 & 548 \\ 1919 & 33 & 1941 & 37 & 1963 & 79 & 1985 & 632 \\ 1920 & 38 & 1942 & 38 & 1964 & 82 & 1986 & 747 \\ 1921 & 37 & 1943 & 39 & 1965 & 84 & 1987 & 819 \\ 1922 & 33 & 1944 & 39 & 1966 & 86 & 1988 & 858 \\ 1923 & 33 & 1945 & 40 & 1967 & 92 & 1989 & 919\end{array}$

86 See Part V and following.

87 The New Zealand Official Yearbook 2010 (Statistics New Zealand, Wellington, 2010) at 329. 


$\begin{array}{llllllll}1924 & 33 & 1946 & 40 & 1968 & 97 & 1990 & 964 \\ 1925 & 34 & 1947 & 44 & 1969 & 101 & 1991 & 973 \\ 1926 & 34 & 1948 & 44 & 1970 & 111 & 1992 & 986 \\ 1927 & 34 & 1949 & 45 & 1971 & 121 & 1993 & 1000 \\ 1928 & 34 & 1950 & 49 & 1972 & 127 & 1994 & 1028 \\ 1929 & 34 & 1951 & 55 & 1973 & 140 & 1995 & 1058 \\ 1930 & 32 & 1952 & 57 & 1974 & 158 & & \\ 1931 & 27 & 1953 & 61 & 1975 & 183 & & \\ 1932 & 27 & 1954 & 62 & 1976 & 211 & & \\ 1933 & 27 & 1955 & 64 & 1977 & 243 & & \\ 1934 & 27 & 1956 & 66 & 1978 & 268 & & \\ 1935 & 29 & 1957 & 68 & 1979 & 312 & & \end{array}$

After plateauing in the 1920s the CPI went downhill in the depression years of the 1930s. The CPI stood at 40 in December 1945, 64 in 195584 in 1965, reaching 111 in 1970. Inflation then took off reaching 363 in 1980 and 964 in 1990, with the rate, although still significant, reducing in relative terms to 1058 in 1995 .

In the last 20 years under the agreement with the Minister of Finance the Reserve Bank has focussed on managing monetary policy to meet the policy targets in the agreement. In broad terms inflation has averaged annually overall at around three per cent. 
